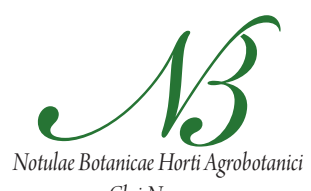

Cluj-Napoca

\title{
EDITORIAL \\ Faculty of Horticulture Cluj-Napoca: Celebrating 35 Years of Horticulture Higher Education
}

\author{
Mugurel I.JITEA, Viorel MITRE, Liviu HOLONEC, Radu E. SESTRAS* \\ University of Agricultural Sciences and Veterinary Medicine, 3-5 Manastur Str., 400372, Cluj- \\ Napoca, Romania; rsestras@usamvcluj.ro (*corresponding author)
}

\begin{abstract}
Although the Faculty of Horticulture from Cluj-Napoca was founded in 1977, the higher education in horticulture has a long and important tradition and history in Transylvania, Romania. It started in 1869, when the Agricultural Institute Cluj, Manastur (today, University of Agricultural Sciences and Veterinary Medicine, Cluj-Napoca), one of the oldest higher education life sciences centres from East-Central Europe, was created. This 'Agronomy Academia' was established due to the efforts of the Transylvanian Agricultural Association and the Status Romano-Catholicus Transylvaniensis, which rented to the Ministry of Agriculture 400 ha of land and the buildings of an old Benedictine monastery near a city that can track its routes back into the Roman Empire. For more than 140 years, the efforts and the predecessors contribution have been creating an important higher education and research institution. In 2012, to celebrate 35 years of excellence, the Faculty Council organised a special event in 'Aula Magna' of the University, in November the 29 ${ }^{\text {th }}, 2012$. It brought together special guests from partner institutions, forebears of the faculty, academic staff, students, graduates and members of the horticultural business, sustaining the Faculty's new mission of being a catalyst for the horticulture education and research. On this occasion, the prestigious honorific title of Doctor Honoris Causa was granted for two academic personalities, related to the faculty: Jaime Prohens, from the Polytechnic University of Valencia, Spain, and Ioan Vasile Abrudan, rector of the 'Transylvania' University from Brasov, Romania.
\end{abstract}

Keywords: academic, horticulture, research, Romania, Transylvania

\section{The history of the Transylvanian higher education in horticulture}

The horticultural academic education has a long tradition in Transylvania, Romania. It started in 1869, when the Agricultural Institute Cluj-Manastur, one of the oldest higher education life sciences centres from East-Central Europe, was created. The Institute was established due to the efforts of the Transylvanian Agricultural Association and the Status Romano-Catholicus Transylvaniensis which rented to the Ministry of Agriculture 400 ha of land and the buildings of an old Benedictine church (Serban, 1938) near the Napoca town (Cluj-Napoca in our days), a city that can track its routes back into the Roman Empire (107 d.C) (Pascu, 1974). Since those times, the Agricultural Institute and then the Agricultural Academy Cluj-Manastur (1906) invested in new academic and research facilities to assure the premises for a high-performing education system (Pamfil et al., 2011). The horticultural endowments were represented by a didactical vineyard and an orchard (21.5 ha), the nurseries ( $3.5 \mathrm{ha})$, but also by an important collection of fruit trees varieties. A vegetable nursery and a garden, and later on a greenhouse, were also created (Indrea, 1993). From 1940 to 1945, the Agricultural Academy was forced to move in Timișoara due to the Vienna
Dictate with teachers, students and a small part of the didactical facilities. In 1946, when the Academy returned in Cluj, some teachers remained there to create a new higher education institution.

From 1945 to 1977 the horticultural education and research had been constantly developing. The academic staff obtained important results in developing new production techniques and technologies, plant breeding and new cultivars in vegetables, floriculture, viticulture and pomiculture. New varieties were homologated; the agrotechnics of the intensive orchards and vineyards, and the zoning of the vegetable crops and the fruit trees in Transylvanian plateau and in the mountains areas were also investigated (Indrea, 1993). The results and their importance, but also an increasing market demand for fresh vegetables and fruits led to the creation, in 1977 of a new academic programme in the area of horticulture. The moment was considered as the starting point of a new academic specialisation, which later, in 1990, became the Faculty of Horticulture. The most important contributions to this achievement have had Prof. Emil Negruțiu (rector); Prof. Ioan Puia (rector); Prof. Zoltan Nagy (vice rector); Prof. Costică Panfil (dean); Prof. Alexandru Salontai (dean, later rector); Prof. Dumitru Mureșan (vice dean). Even though from the administrative point of view, the horticulture education and 
2

research celebrated 35 years of existence in 2012, its history is much deeper, linked directly to the evolution of the University of Agricultural Sciences and Veterinary Medicine from Cluj-Napoca (Sestras et al., 2012a; 2012b).

Until 1990, the academics and the researches in the horticultural areas were developed in the Faculty of Agriculture and Horticulture. In January 1990, the University Senate decided to create a new administrative structure devoted to the development of the Transylvanian higher horticultural education - The Faculty of Horticulture.

\section{The Faculty of Horticulture in our days}

In the last years, the Faculty of Horticulture from Cluj-Napoca has constantly developed and adapted to the conditions, realities and the social demands of the labour market. While improving its structure, new academic programs were created and important investments in the academic staff and in the research infrastructure were made. In the academic area, new programmes were developed in horticulture but also in related education fields. Bachelor programs namely, Management of the Rural Development (1997), Forestry (2001), Landscape Design (2002), Engineering and Management of the Agro-Alimentary Industry and Agro-Tourism (2002), Land Measurement and Cadastre (2005) and Management and Engineering of the Tourism Industry (2010) completed the academic offer of the Faculty. Besides the bachelor programs, the ten masters and the doctoral programs transformed the unit in one of the most attractive faculties, reaching almost 2500 students in all Bologna cycles coming from all Romanian territory, but also from abroad.

The outstanding teaching facilities include dedicated teaching staff, cutting-edge equipment and experimental teaching laboratories. The presence of a vast nearby agrobotanical garden, an experimental orchard, a vineyard and the greenhouses represent valuable open-air study facilities, as well as inspirational surroundings for the cultural designed landscape. Facilities are extensive and include state-of-the-art equipment and expertise in horticulture sciences and many other life sciences areas.

Research has, more than ever, an essential role and a privileged status. Its goal is to find relevant answers to some of the most important challenges of the twenty first century such as: to ensure food security and safety for all members of our society, to reduce pollution, to ensure a sustainable management of the natural resources with which we have been endowed, to assure the conservation of biodiversity, and to increase the living standards of the rural population (European Commission, 2010). The multidisciplinary researches cover broad relevant areas. In horticulture, the research deals with: the study and the conservation of the germplasm of various horticultural species, to obtain new genotypes of horticultural plants, to use biotechnological techniques and genetic engineering in improving plants' tolerance or resistance to different stress factors, to optimise and to improve the production techniques to the main flower, vegetable, dendrologic, orchards and vineyards species. In the forestry field, our researches are aimed to identify which are the main methods of preserving biodiversity, to ensure the forestry bio conservation and the ecological reconstruction of the forest areas affected by natural disasters. Land reclamation as well as the topographic methods of land and buildings monitoring are other fundamental research concerns. Last but not least, the socio-economic research of the rural area, the agriculture and rural development policy are other directions validated by outstanding results. The privileged research status is confirmed by the high performing infrastructure. It is concentrated in two research centres and several research laboratories that cover all the relevant research topics (Sestras et al., 2012a; 2012b).

After 1990, a special contribution in the constant growth of the Faculty of Horticulture has been made by the rectors of the University of Agricultural Sciences and Veterinary Medicine Cluj-Napoca (Prof. Leon Sorin Muntean, 1990-2000; Prof. Liviu Alexandru Mărghitaș, 2000-2008; Prof. Doru Pamfil, 2008-2012; 2012-), the deans of the Faculty (Prof. Dumitru Indrea, 1990-1992; Prof. Dumitru Zaharia, 1992-1996; Prof. Marin Ardelean, 1996-2004; Prof. Silviu Al. Apahidean, 2004-2008; Prof. Radu E. Sestras, 2008-2012; 2012-) and all the academic and the research staff.

\section{$35^{\text {th }}$ years of Transylvanian higher education 1977-2012, $29^{\text {th }}$ of November 2012}

In the past few years, the Faculty has proved to be a social catalyst between scientists, students and agribusiness from Transylvania, Romania. This new mission sustains the initiative of the Faculty Council to organise a festive event for celebrating the 35 years of excellence in education and research in the field of horticulture. It was a moment of great joy for the academic staff, guests from partner institutions, agribusiness, the graduates and the students of the Faculty.

The ceremony took place in the Aula Magna "Mihai Serban" of the University of Agricultural Sciences and Veterinary Medicine, Cluj-Napoca, on the $29^{\text {th }}$ of November, 2012, according to the following schedule:

-Welcome speech given by the Rector of the University of Agricultural Sciences and Veterinary Medicine ClujNapoca, Prof. dr. Doru Pamfil.

-"35 Years of Horticulture Education in Cluj-Napoca, 1977-2012" - 35 Years of Excellency - presentation held by the Dean of the Faculty of Horticulture Cluj-Napoca, Prof. dr. Radu E. Sestras.

-Anniversary messages

-Granting the title of "Doctor Honoris Causa" to Prof. dr. Jaime Prohens, Polytechnic University of Valencia, Spain ("Laudatio" - Prof. dr. Viorel Mitre).

-Granting the title of "Doctor Honoris Causa" to Prof. dr. Ioan Vasile Abrudan, rector of the Transylvania University Braşov ("Laudatio" - Conf. dr. Liviu Holonec) 
-Chamber Concert

-Gala Dinner, held at the Biodiversity Research Centre, UASVM Cluj-Napoca.

During the ceremony, Rector Doru Pamfil emphasised that the tradition of horticultural higher education in Transylvania comes together with the history of the University, with more than 140 years of age. Thus, in the images from those early times (1869), the ancient city of Cluj appears to be surrounded by hills covered with vineyards and fruit trees. After 1990, the Faculty of Horticulture created its own way in the University; it developed new programs and today is becoming the most important institution from the University in terms of the number of students. Finally, Rector Pamfil congratulated the entire academic staff and he expressed his belief that by accomplishing the new Advanced Horticultural Research Institute of Transylvania, the academics and the scientific research will experience unprecedented developments in the future.

The dean of the Faculty, Radu E. Sestras, presented the most important moments in the development of the horticultural higher education. Since its creation, the Faculty has been continuously developing and establishing new bachelor and master programs. In parallel, research has been developing through the establishment of several research centres and laboratories, editing journals with national and international recognition, or the development of national and international research projects. Finally, the dean thanked the University (rectors) and the Faculty (past-deans) managers for their involvement in the development of this prestigious institution.

Anniversary messages were presented, starting with a video greeting given by Dacian Ciolos, European Commissioner for Agriculture and Rural Development, a graduate of Faculty of Horticulture from Cluj-Napoca, followed by a message of Ministry of Education, Prof. dr. Ecaterina Andronescu.

Also, anniversary messages were transmitted by administrative staff and scientific personalities from Romanian academic units, which participated at the event: Sorin Mihai Cîmpeanu, rector UASVM Bucureşti; Gheorghe Glăman, president of Romanian Society of Horticulture; Lucia Drăghia, dean, Faculty of Horticulture, UASVM Iaşi; Dorel Hoza, dean, Faculty of Horticulture, UASVM București; Toma Adrian Dinu, dean, Faculty of Economics and Management, UASVM Bucureşti; Marin Soare, dean, Faculty of Agriculture and Horticulture, University from Craiova; Gheorghe Poşta, vice dean, Faculty of Horticulture and Silviculture, UASVM-B, Timişoara; Sergiu Horodnic, dean, Faculty of Silviculture, University of Suceava; Lucian Curtu, dean, Faculty of Silviculture, 'Transilvania’ University, Braşov.

\section{Doctor Honoris Causa awards}

In Romania, the title of "Doctor Honoris Causa" is the highest academic distinction given to personalities with exceptional achievements in scientific and academic activities, or who have unique contributions to the development of science.

The faculty awarded the last highest honorific DHC title in 2010, when following the proposal of Academic Council of Horticulture Faculty from Cluj-Napoca, the Senate of University of Agricultural Sciences and Veterinary Medicine accepted nominee Professor Jules Janick for "Doctor Honoris Causa" award. The title was awarded in a festive ceremony on September 30, 2010, Jules Janick, professor at Purdue University, being recognised for a long and distinguished career devoted to horticulture in all its facets (Sestras, 2010).

Based on the similar process, for the $29^{\text {th }}$ of November 2012 event, the University Senate decided, after the proposition of the Faculty Council to award the Doctor Honoris Causa title to Professor Jaime Prohens, from the Polytechnic University of Valencia, Spain, and to Professor Ioan Vasile Abrudan, rector of the University 'Transylvania' from Brasov, Romania, for their constant effort, respectively, in the development of horticulture and forestry sciences.

\section{Professor Jaime Prohens}

In the Laudatio message for Professor Jaime Prohens Doctor Honoris Causa award the most important achievements of the nominee and his contributions related to the Faculty of Horticulture from Cluj-Napoca were presented. Prof. Dr. Jaime Prohens is Engineer in Agronomy and Doctor Engineer in Agronomy. He is Full Professor of Genetics and Plant Breeding at the Polytechnic University of Valencia. His main research topic concerns vegetables crops breeding and the integration of conventional methods and new biotechnologies with the final aim of developing new cultivars of vegetables. In the same time, he developed an important task in the promotion of the national and international research activity in plant breeding and horticulture, by presiding over the European Association Research on Plant Breeding (EUCARPIA) and also the Spanish Society for Horticultural Sciences. He has also devoted time to the administration at the University level, by being director of the Department of Biotechnology and the Institute for Conservation and Improvement of Agrodiversity (COMAV), two of the most relevant research structures of the Polytechnic University of Valencia. Prof. Dr. Jaime Prohens has obtained seven cultivars of Solanum crops adapted to Mediterranean conditions; he has also had an important activity in the prospection and conservation of genetic resources, with 12 scientific expeditions in South America, where he has made an important contribution to the understanding of the distribution and ecology of wild relatives of Andean crops. During these expeditions, he discovered two new wild species of the potato-tomato-pepino group: Solanum catilliflorum and Solanum perlongistylum. He is author of more than 240 scientific papers and publications, and has 
4

had an important editorial activity and received awards and recognitions related to research. In addition, he has had an important activity of technology transfer, including transfer of improved cultivars and plant material and associated technology, as well as participation in courses and technology transfer workshops.

In his address upon receiving the title, Professor Jaime Prohens had mentioned: "...It is for me, a plant breeder and geneticist, an immense pleasure and great honour to accept, in all humility and with sincerest gratitude, the highest academic title of Doctor Honoris Causa from the University of Agricultural Sciences and Veterinary Medicine Cluj-Napoca. I accept this award on behalf of the millions of farmers, agronomists, and breeders who have made a contribution to the development of the crops and cultivars that provide us with an abundant supply of diverse, healthy, and tasteful food, as well as with many other commodities. For me, this award is a recognition of the importance of plant breeding for our daily lives. The new cultivars with high yield, together with improved agronomic techniques, have released many people, including most of us, from the hard, although noble, work of peasantry. This has resulted in a societal revolution, which in the end has allowed the development of modern and free societies".

\section{Professor Ioan Vasile Abrudan}

The Laudatio message delivered for Doctor Honoris Causa award, showed that Ioan Vasile Abrudan, distinguished professor, Rector of 'Transilvania' University from Brașov, Romania, is a scientific personality with a large national and international recognition. He obtained the title of Forestry Engineer in the Faculty of Forestry from Brasov University, Romania, and the Doctorate from Brasov University and Brunel University. He has been involved in the development of 53 research projects, as director, coordinator or research coordinator, with the European Commission, the World Bank, FAO, Prototype Carbon Fund (USA), United States Agency for Development, the European Bank for Reconstruction and Development, the Carpathian Ecoregion Initiative, World Wildlife Fund, United Nations Development Programme, United Nations Environment Programme, the Department for Environment, Food and Rural Affairs in the UK, BBI Matra, Netherlands, the Romanian Ministers, and the private sector. The contribution to the development of scientific knowledge is represented by more than 110 papers indexed in databases, such as ISI-WoK/WoS, Scopus, CAB International, Springer, Forest Science Database, IUFRO, U.S. Congress Library Database, ZETOC (British National Library) etc. Most of the papers focus on three subdomains, related to the research and teaching activities: (1) afforestation (seeds, nurseries, and forestry crops installation); (2) protected areas/biodiversity conservation, and (3) policies, strategies and forest management. He is coeditor and member of editorial board of different journals, and was part of the Technical Advisory Group for Forestry Policies and Strategies of the World Bank (Washington, USA). Also, he is member in the board of the Carpathian Ecoregion Initiative (Bratislava, Slovakia), member of IUFRO and member of FSC (Bonn, Germany). In 2009, he was elected as the first President (Chair) of the Conference of the Deans and Directors of European Forestry Faculties and Schools, an association that brings together 28 institutions from Europe. Regarding administrative management, he was dean of the Faculty of Silviculture and Forest Engineering (2004-2012), and from February 2012 became Rector of 'Transylvania' University from Brasov, Romania; in addition, Professor Abrudan occupied high positions in national ministerial education structures (eg. The Romanian Agency for Quality Assurance in Higher Education - ARACIS; National Council for Attestation of Academic Titles, Diplomas and Certificates - CNATDCU; National Council for Financing Higher Education - CNFIS). He has received numerous certificates and awards among which are: the Diploma of Honor Ingeniero de Montes, Madrid, Spain (2009), Doctor Honoris Causa award of the University of Agricultural Sciences and Veterinary Medicine of Banat, Timisoara (2010), Honorary Professor of Buckinghamshire New University, United Kingdom (2011), Visiting Professor of Shenyang Jianzhu University, China (2012).

\section{References}

European Commission (2010). Communication from the Commission-Europe 2020. A strategy for smart, sustainable and inclusive growth. Brussels, European Commission.

Indrea D. (1993). Retrospect and prospects of horticultural higher education and research in the University of Agricultural Sciences Cluj-Napoca (in Romanian). Bulletin UASVM Horticulture 47(1):1-19.

Pamfil D, Pop I-A, Bolovan I (2011). Tradition and innovation in agricultural education in Transylvania: the History of University of Agricultural Sciences and Veterinary Medicine Cluj-Napoca (in Romanian). AcademicPres, Cluj-Napoca.

Pascu S (1974). The Cluj History (in Romanian). Cluj-Napoca.

Serban M. (1938). The Academy of Higher Agronomical Studies Cluj (in Romanian). Cartea Romaneasca, Cluj.

Sestras R. (2010). Tribute to a Leading Personality of World Horticultural Science. Not Bot Horti Agrobo 38(3):9-14.

Sestras RE, Mitre V, Jitea MI, Zaharia A, Maniutiu D, Holonec L, Arion FH, Ortelecan M (2012a). Faculty of Horticulture: 35 years of horticultural education in Cluj-Napoca (1977-2012) (in Romanian). AcademicPres, Cluj-Napoca.

Sestras RE, Mitre V, Jitea MI, Zaharia A, Maniutiu D, Holonec L, Arion FH, Ortelecan M (2012b). Faculty of Horticulture Cluj-Napoca: tradition and innovation in education and research. AcademicPres, Cluj-Napoca. 

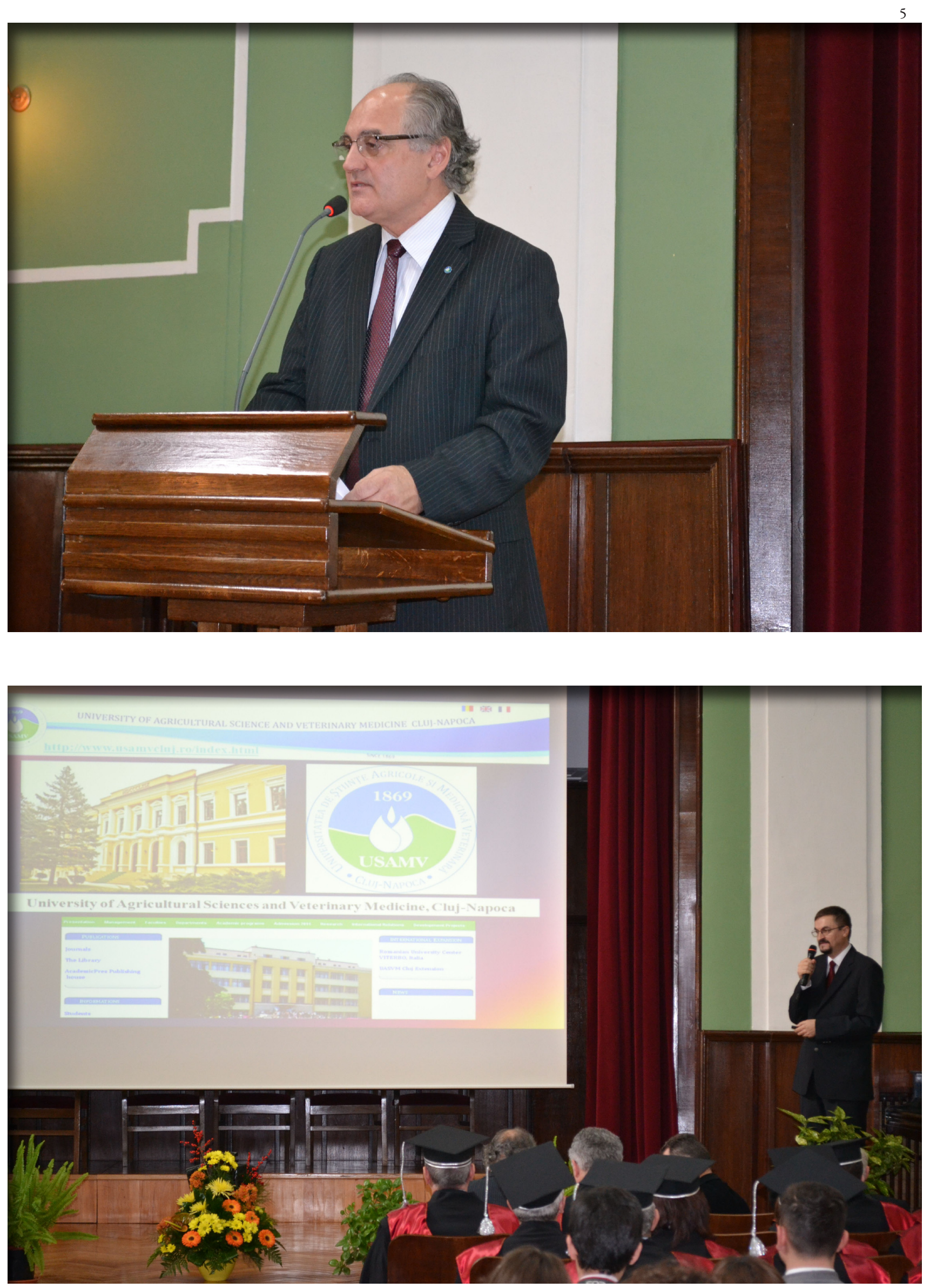

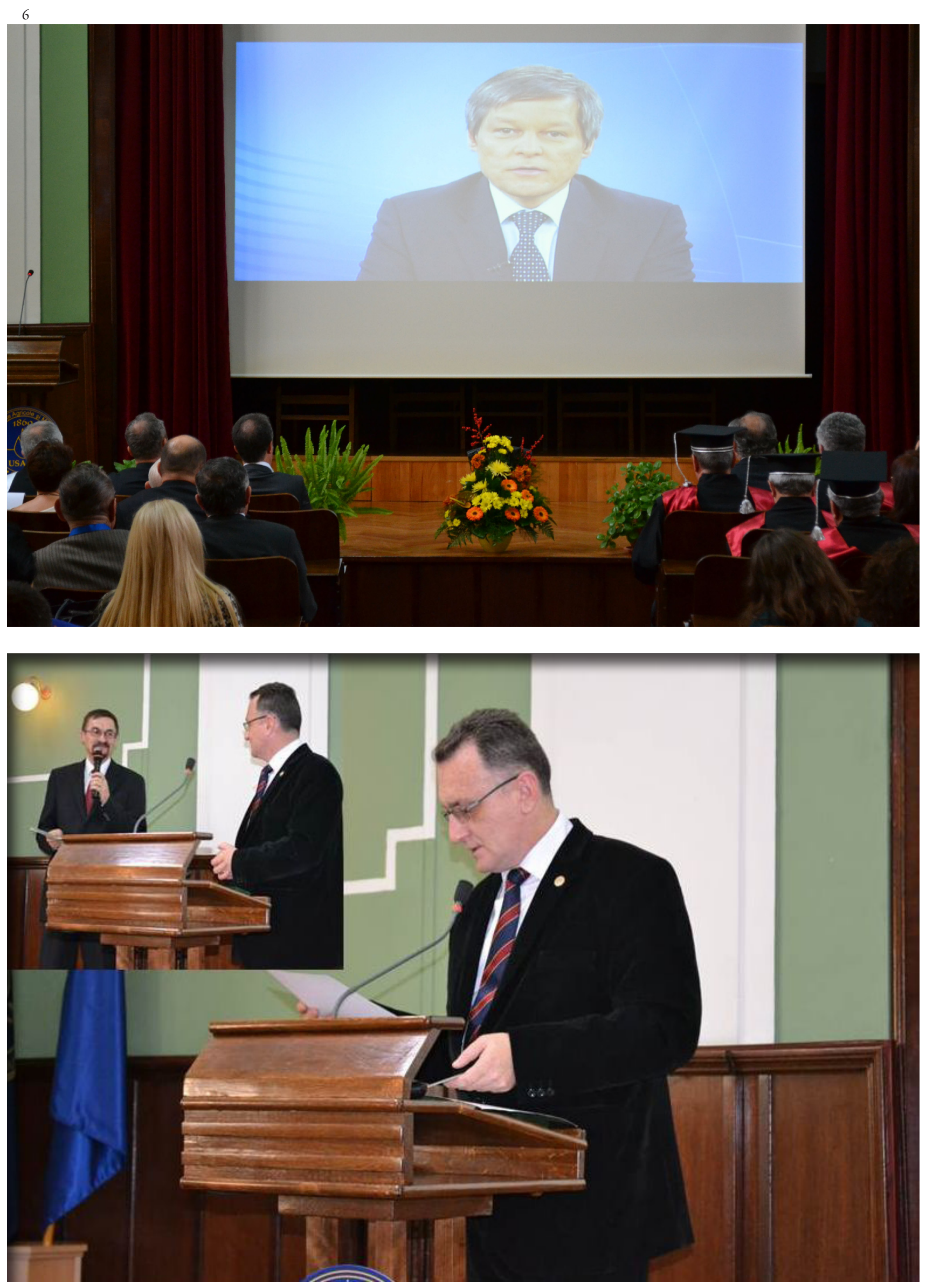

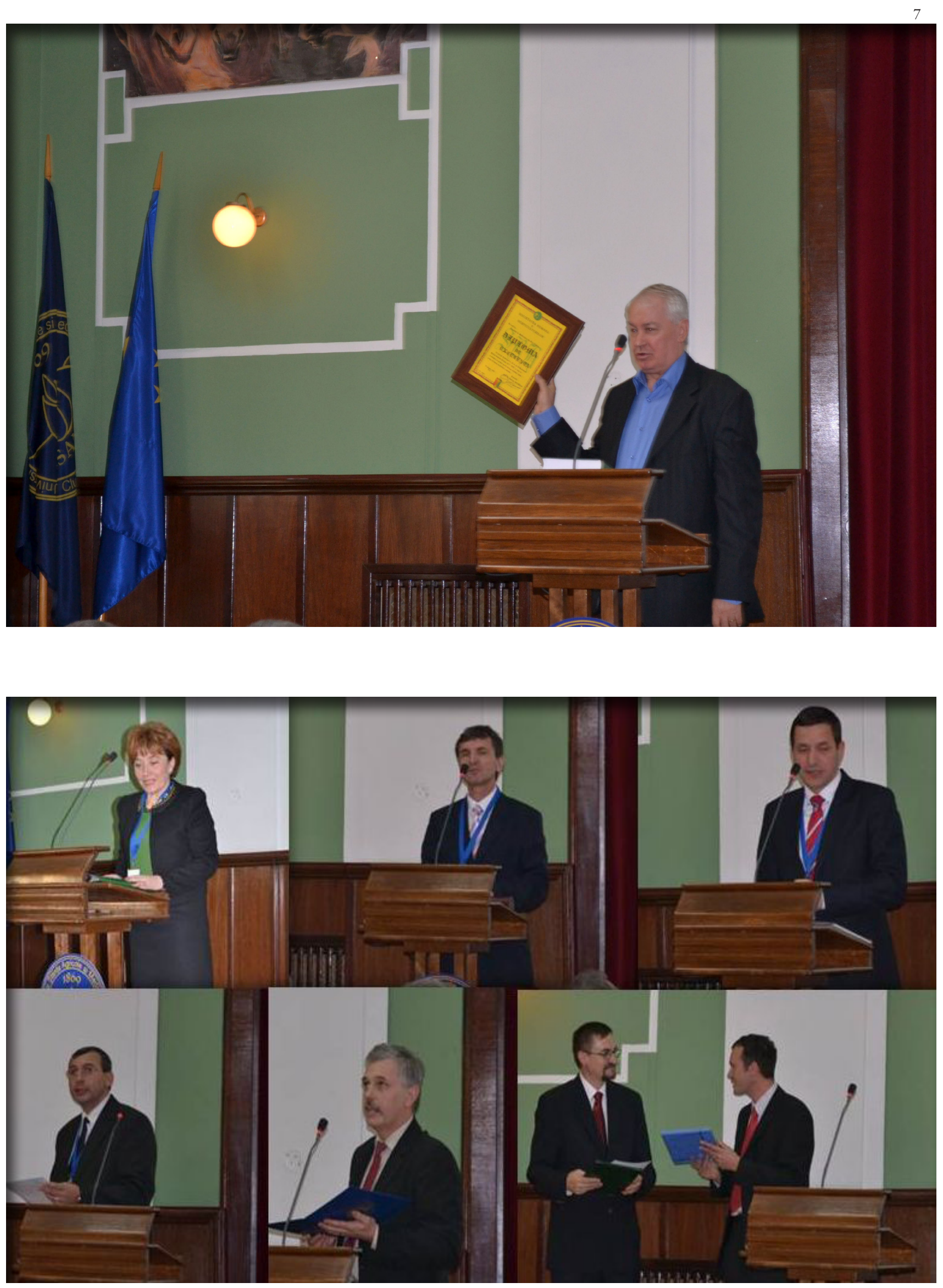

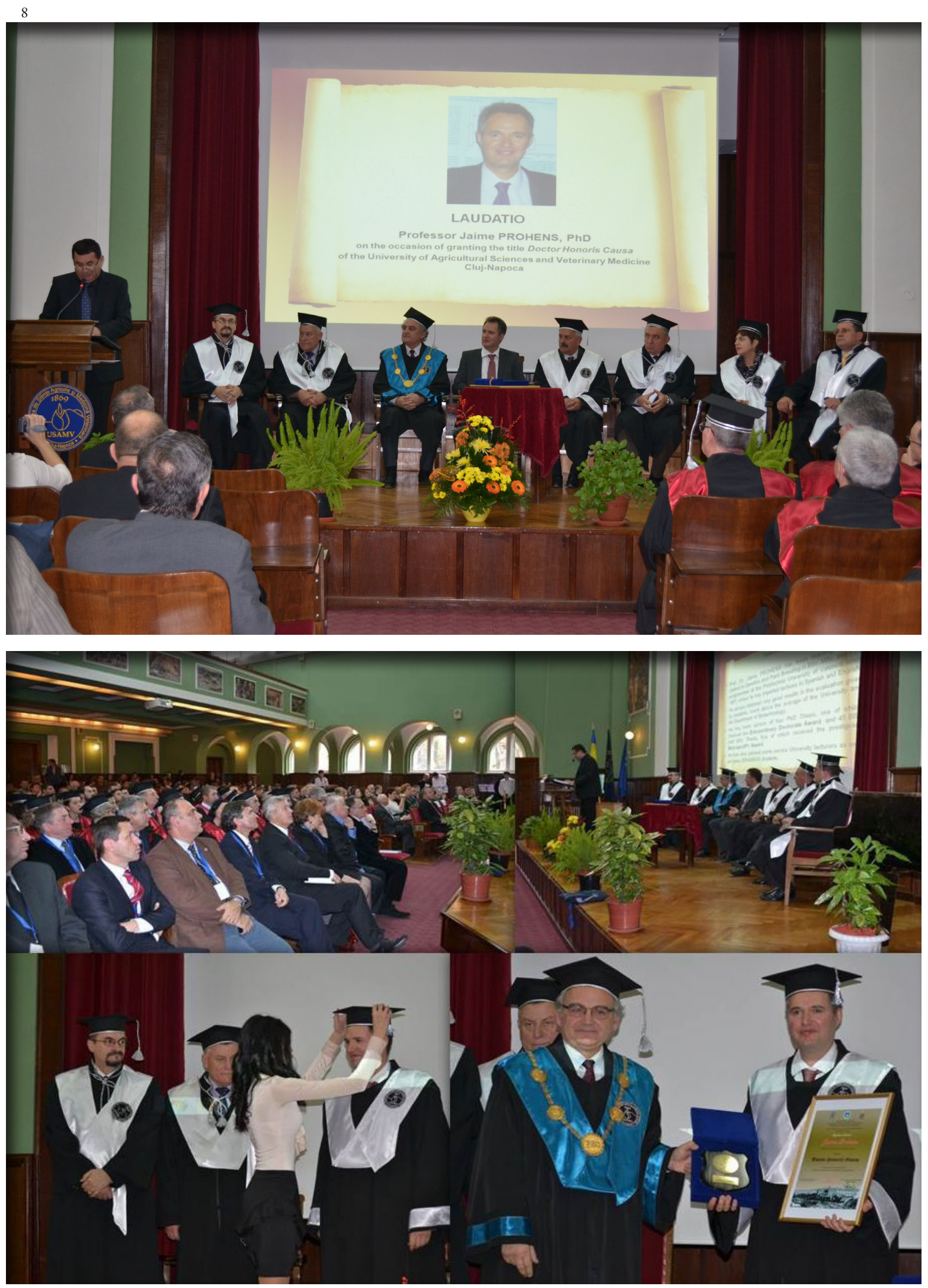

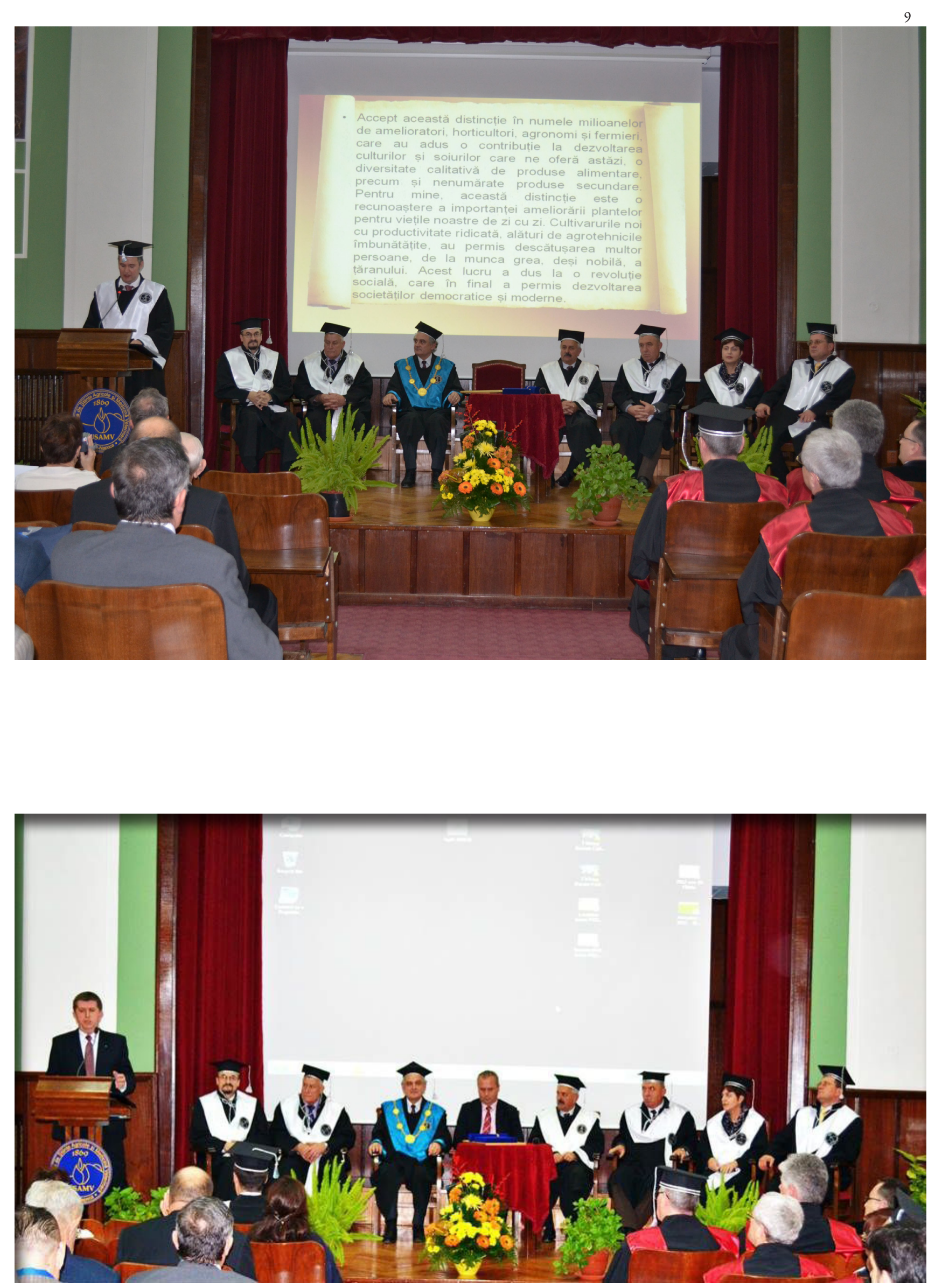


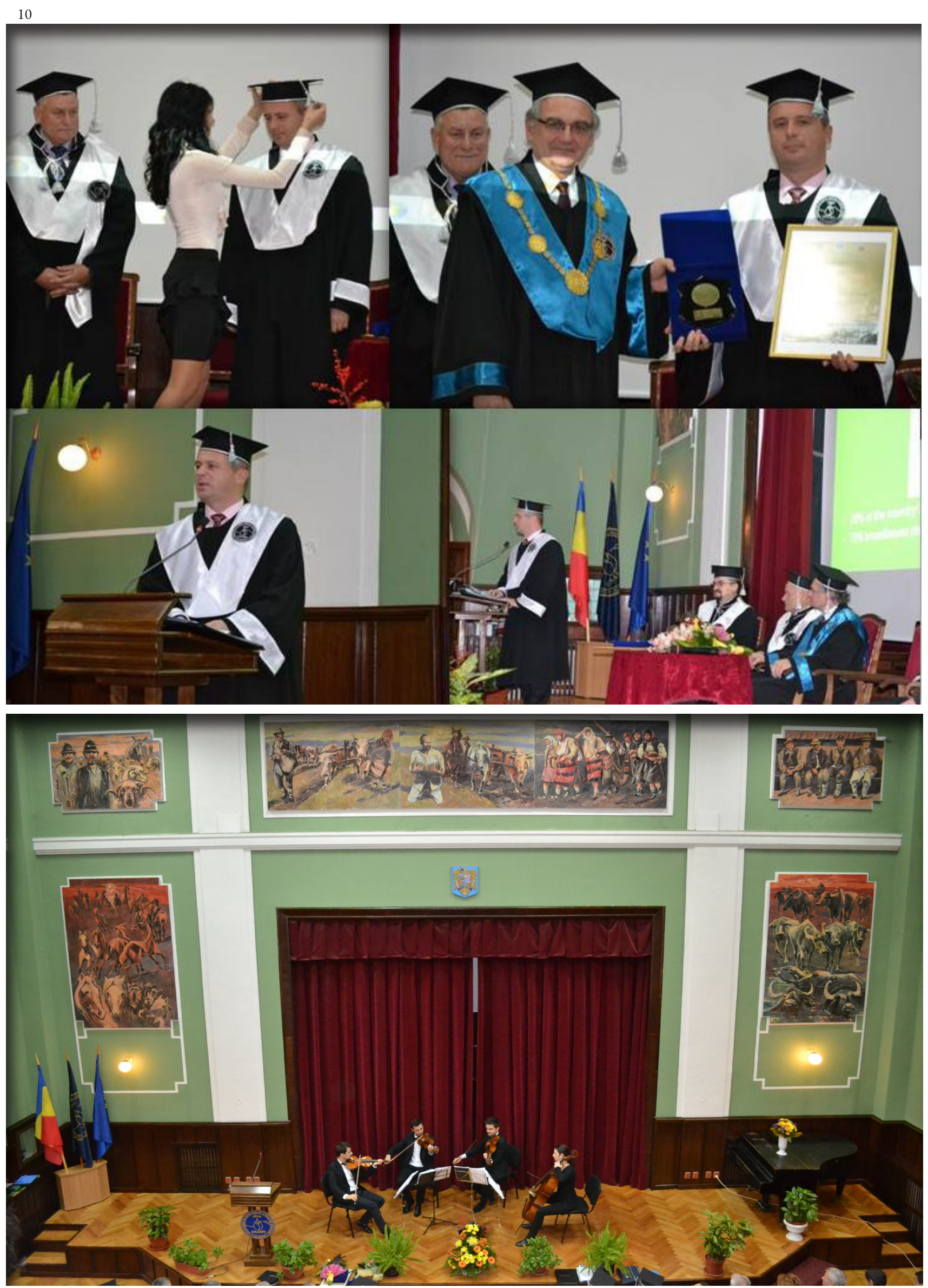




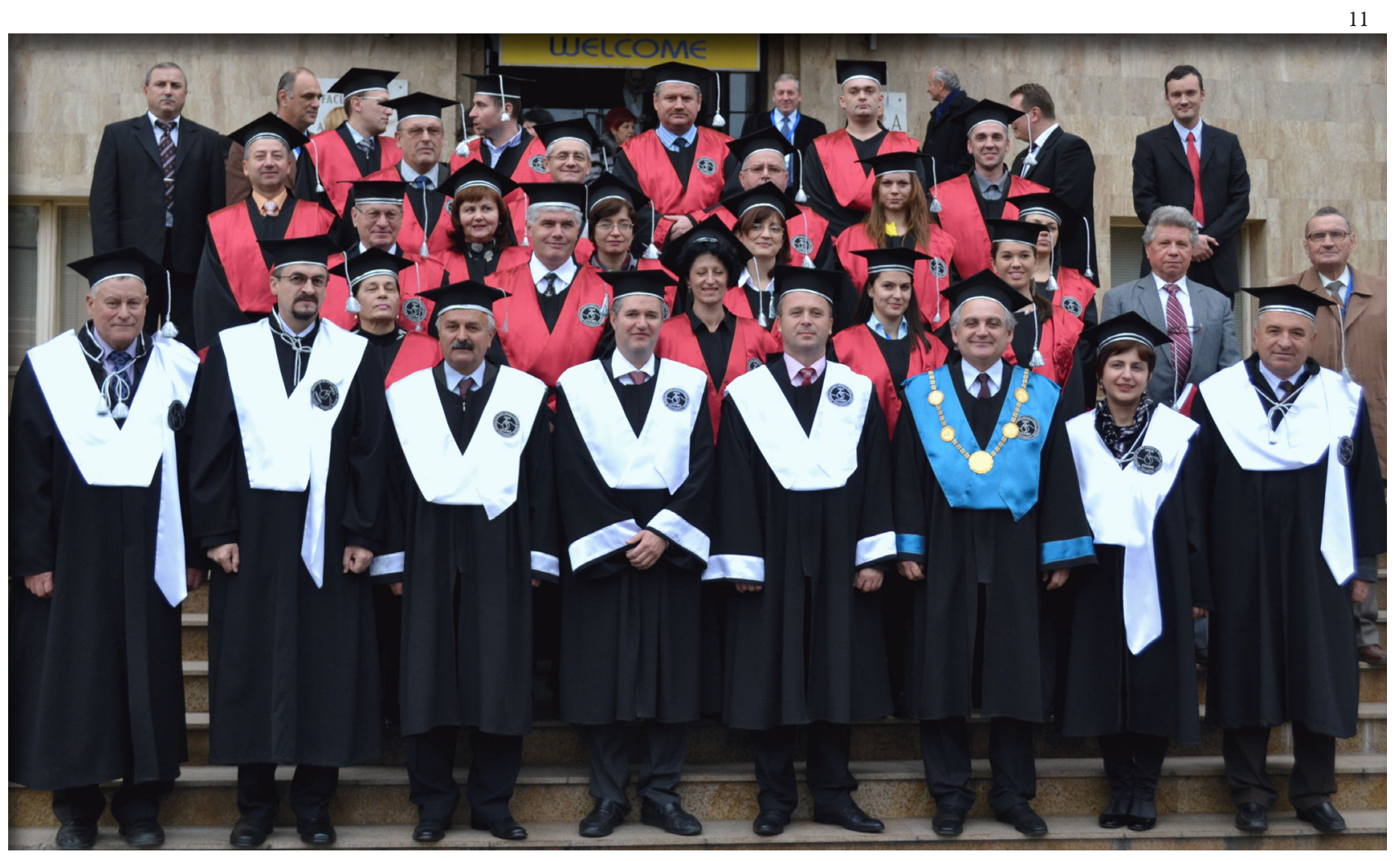

\section{Doctor honoris Gausa}

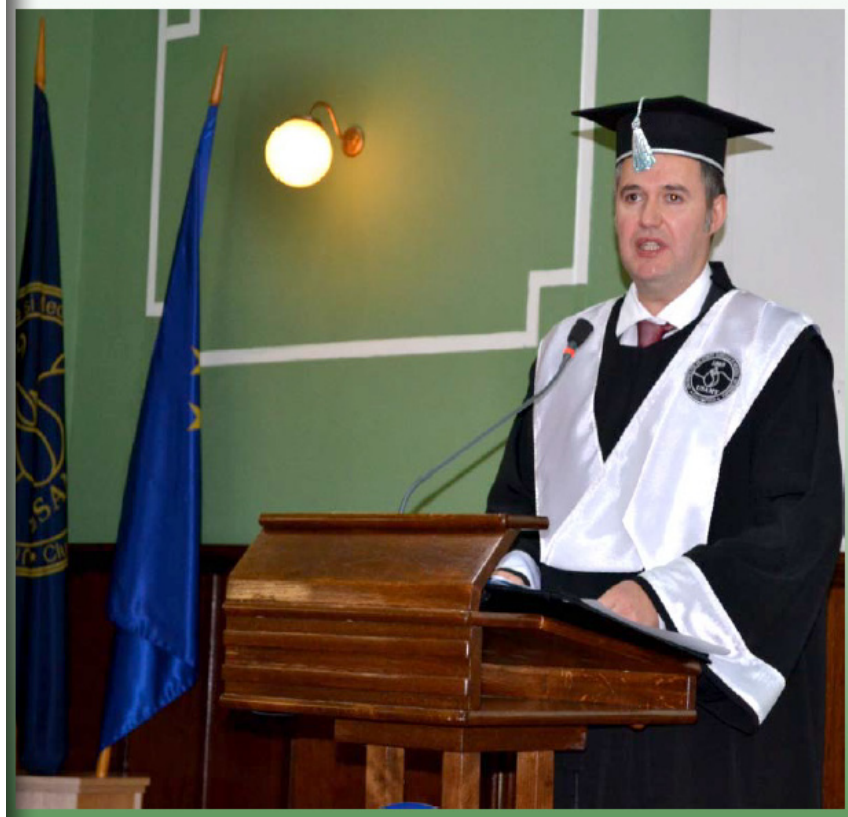

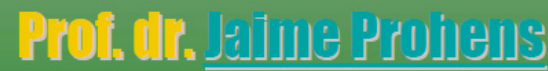
Universitatea Politohnien Ualonsla

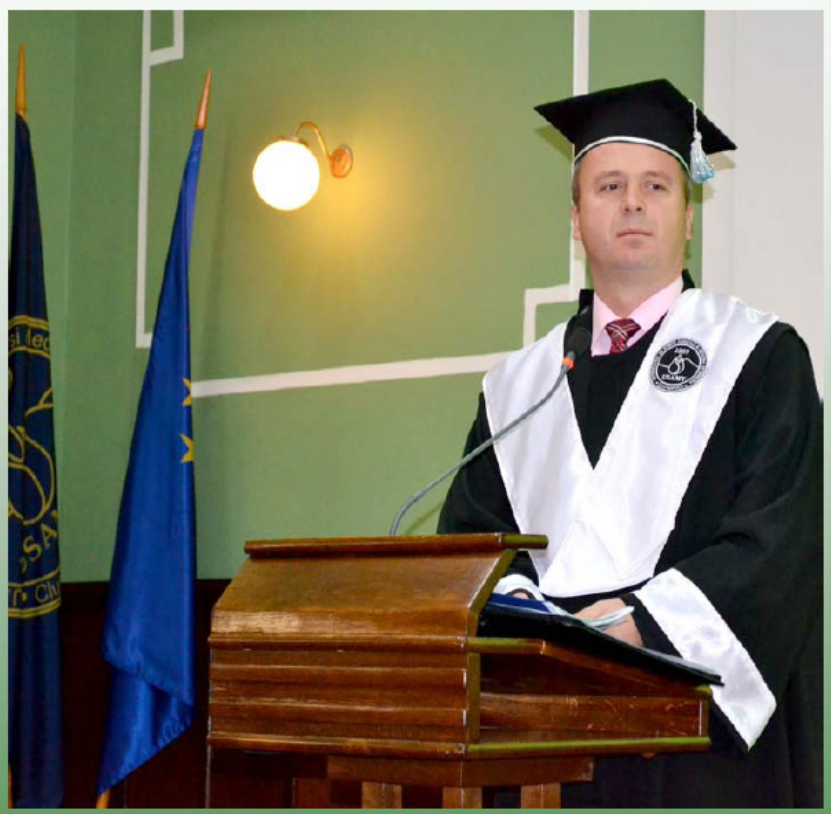

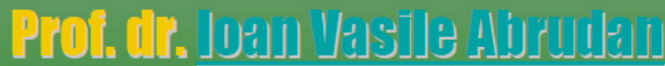
Roctornl Onivorsiltụit Transilurania Brasol 